NESIR $82-2496$

\title{
Determination of Water in Plutonium Dioxide
}

U.S. DEFARTMENT OF COMMEFICE

Natioral Bureau of Standards

Washington, DC 20234

\section{April 1982}

Finai Recort

-

100 e of Safeguards $P$ Securment of Energy

.456 lington, DC 20545

ó2-2496

1932

C.2 

Frank E. Jones

U.S. DEPARTMENT OF COMMERCE

National Bureau of Standards

Washington, DC 20234

April 1982

Final Report

Prepared for:

Office of Safeguards \& Security

U.S. Department of Energy

Washington, DC 20545

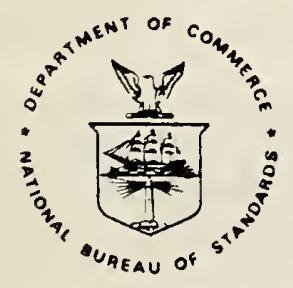

U.S. DEPARTMENT OF COMMERCE, Malcolm Baldrige, Secretary NATIONAL BUREAU OF STANDARDS, Ernest Ambler, Director 

Determination of Water in Plutonium Dioxide

Frank E. Jones

\author{
Fluid Engineering Division \\ Center for Chemical Engineering \\ National Bureau of Standards \\ Washington, DC 20234
}

Techniques developed to very effectively apply automatic Karl Fischer reagent titration to the determination of $\mathrm{H}_{2} \mathrm{O}$ in solids were used to determine the moisture content of samples of plutonium dioxide powder under the constraints imposed by the necessity of working in a glove box. The moisture contents of three samples were found to be $0.2934 \%, 0.7298 \%$, and $0.4640 \%$. The estimate of the relative standard deviation of the mean for three determinations on the $0.2934 \% \mathrm{H}_{2} \mathrm{O}$ sample was 0.0091 . The method apparently has potential as the basic reference method for determination of $\mathrm{H}_{2} \mathrm{O}$ in plutonium dioxide, as a means of standardizing other methods, and as a diagnostic tool.

Key Words: Automatic titration; Karl Fischer reagent titration; moisture; nuclear safeguards; plutonium dioxide; water determination.

\title{
1. Introduction
}

The interaction between water and plutonium dioxide has been studied by Stakebake $[1,2,3]^{1}$ and others. The exchange of water vapor between plutonium dioxide $\left(\mathrm{PuO}_{2}\right)$ and its environment is considered to be one of the sources of differences in the plutonium content of the oxide as determined by shippers and receivers. In a program on the determination of the moisture content of $\mathrm{PuO}_{2}$, techniques were developed to very precisely apply automatic Karl. Fischer reagent titration to the determination of $\mathrm{H}_{2} \mathrm{O}$ in solid materials. Measurements have been made on uranium oxides, titanium dioxide, and other metal oxides. This note reports the determinations of $\mathrm{H}_{2} \mathrm{O}$ in $\mathrm{PuO}_{2}$ using an automatic Karl Fischer reagent titrator and modified techniques under the constraints imposed by the necessity of working in a glove box. The work was performed at the Hanford Energy Development Laboratories at Richland, WA.

\section{Experimental Part}

The apparatus and reagents are described in a previous paper [4]. Since the titrations were to be made in a glove box, it was necessary to slightly modify the apparatus. The reaction vessel of the titrator was placed inside the glove box on the base of a magnetic stirrer; the generator leads and the sensing electrode leads

\footnotetext{
Numbers in brackets indicate the literature references at the end of the paper.
} 
were extended and attached to a "bulkhead" connector mounted on the face of the glove box. Leads connected the connector outside the glove box to the binding post on the base which enclosed the electronics of the titrator. The mixer/mill (used to mill the oxide in methanol to extract the $\mathrm{H}_{2} \mathrm{O}$ ), without the cover, was installed inside the glove box.

Three samples (ca. $15 \mathrm{~g}$ each) of $\mathrm{PuO}_{2}$ powder from three different suppliers (Los Alamos Scientific Laboratories, Los Alamos, NM; Rockwell Hanford Operations, Richland, WA; and Savannah River Plant, Aiken, SC) were used in the determination of $\mathrm{H}_{2} \mathrm{O}$. It was not practical to run replicate samples. Each sample was weighed on an analytical balance. The sample and three tungsten carbide pellets were put into the milling vessel of the mixer/mill and $25 \mathrm{~mL}$ of methanol was pipeted into the vessel from a Class A pipet. The lid was sealed and the sample was milled in the methanol for $15 \mathrm{~min}$. The vessel was then set aside for ca. $42 \mathrm{~h}$ during which time the solid residue settled to the bottom. The milling and succeeding procedures were repeated for $25 \mathrm{~mL}$ of methanol without sample, to prepare a blank.

Calibrated syringes [5] of 1-mL capacity were used to withdraw 0.5-mL quantities of methanol-extracted $\mathrm{H}_{2} \mathrm{O}$ mixture from the milling vessels and introduce them into the reaction vessel of the titrator; $2.5-\mathrm{mL}$ quantities of the methanol blank were introduced from a 5-mI capacity uncalibrated syringe. A specimen or a blank was introduced into the titration vessel, titration was started, and after the endpoint was reached the mass of $\mathrm{H}_{2} \mathrm{O}$ titrated as indicated by the counter on the titrator was noted.

The titrator was standardized using a mixture of methanol and water. The mixture was prepared at the National Bureau of Standards by mixing $2 \mathrm{~mL}$ of distilled water with $250 \mathrm{~mL}$ of methanol. Ten milliliters of the mixture was injected into each of seven evacuated test tubes through rubber stoppers using a 10-mL capacity "gastight" syringe which had been rinsed with methanol and heated in an oven at about $84^{\circ} \mathrm{C}$. After filling, molten paraffin was poured into the concavity in the stopper and then the stoppered end of the test tube was dipped into the paraffin as a precautionary measure to further seal the hole made by the syringe needle and to immobilize the stopper. The titer of the mixture was determined using a titrator which was standardized [4] with distilled water.

\section{Results and Discussions}

The moisture content, $\% \mathrm{H}_{2} \mathrm{O}$, of the samples of $\mathrm{PuO}_{2}$ was calculated [4] using the equation

$$
\% \mathrm{H}_{2} \mathrm{O}=\left(\mathrm{VC} / 10^{6} \mathrm{~m}_{g}\right) \times\left\{\left[\mathrm{Z}\left(\mathrm{A}_{\mathrm{s}} / \mathrm{v}_{\mathrm{s}}\right)-\left(\mathrm{A}_{\mathrm{b}} / \mathrm{v}_{\mathrm{b}}\right)\right] /\left[1-\left(\mathrm{ZC} / 10^{6} \mathrm{p}\right)\left(\mathrm{A}_{\mathrm{s}} / \mathrm{v}_{\mathrm{s}}\right)\right]\right\} \times 100
$$

where $\mathrm{V}$ is the volume $(25 \mathrm{~mL})$ of methanol used for extraction, $\mathrm{C}$ is the standardization factor for the titrator $(\mu \mathrm{g} / \mu \mathrm{g}), \mathrm{m}_{\mathrm{g}}$ is the mass $(\mathrm{g})$ of the $\mathrm{PuO}_{2}$ sample, $\mathrm{Z}$ (dimensionless) is a factor which takes ${ }^{g}$ account of the fact that the volume of a methanol- $\mathrm{H}_{2} \mathrm{O}$ mixture is less than the sum of the volumes the components would occupy separately, $A$ is the titration value ( $\mu \mathrm{g}$ of $\mathrm{H}_{2} \mathrm{O}$ ) for the specimen of methanolextracted $\mathrm{H}_{2} \mathrm{O}^{\mathrm{S}}$ mixture, $\mathrm{V}$ is the volume (mL) ot the specimen. A is the titration value for the methanol blank, $v_{b}$ is the volume of the blank, and $\rho$ is the density of water $\left(\mathrm{g} / \mathrm{cm}^{3}\right) \cdot \quad Z$ is calculated ${ }^{b}[6]$ using the equation

$$
z=1-1.985 \times 10^{7} \times C \times\left[\left(A_{s} / v_{s}\right)-\left(A_{b} / v_{b}\right)\right]
$$

where the units on the numerical coefficient in the second term are $\mathrm{mL} / \mathrm{\mu g}$. The results are listed in Table 1. 
Table 1. Results for Karl Fischer titration $\mathrm{H}_{2} \mathrm{O}$ determinations on $\mathrm{PuO}_{2}$

$\begin{array}{ccc}\begin{array}{c}\text { sample } \\ \text { no. }\end{array} & \% \mathrm{H}_{2} \mathrm{O} & \text { mean } \% \mathrm{H}_{2} \mathrm{O} \\ 1 & 0.2979 & 0.2934 \\ & 0.2887 & \\ & 0.2935 & \\ & 0.7355 & 0.7298 \\ 2 & 0.7240 & \\ & 0.4777 & 0.4640 \\ 3 & 0.4502 & \end{array}$

The results indicate that the techniques described in a previous paper [4] for the application of automatic Karl Fischer titration to the determination of $\mathrm{H}_{2} \mathrm{O}$ in solid materials, modified in the present case, produced very satisfactory results despite the constraints imposed by the necessity of working in a glove box. The estimate of the relative standard deviation of the mean is about $1 \%$ relative in the range 0.3 to $0.7 \% \mathrm{H}_{2} \mathrm{O}$ which can be compared with a value of $0.37 \%$ relative at $0.2758 \% \mathrm{H}_{2} \mathrm{O}$ in titanium dioxide achieved under nearly ideal laboratory conditions [4] by an analyst experienced in the method.

For comparison of the Karl Fischer titration results with those obtained routinely on $\mathrm{PuO}_{2}$ at the Hanford Energy Development Laboratories, samples (ca. 200 mg) were analyzed on a DuPont Model $902 \mathrm{H}$ Moisture Evolution Analyzer (MEA) ${ }^{1}$ at $400^{\circ} \mathrm{C}$ "to equalization." The results corresponding to samples no. 1, 2, and 3 in Table 1 are $857 \mathrm{ppm}, 7044 \mathrm{ppm}$, and $4997 \mathrm{ppm}$, respectively. Since the MEA result was much lower than the titration result for sample no. 1 and since it was not practical to make a titration determination on another $15 \mathrm{~g}$ sample, two more samples taken from different places in the can were subsequently analyzed on the MEA. The results, 735 $\mathrm{ppm}$ and $750 \mathrm{ppm}$, were also much lower than the titration result in Table 1 . The ratio of the MEA result to the titration result for samples no. 2 and 3 are 0.9652 and 1.077; the ratio for the largest MEA value for sample no. 1 is 0.292 . The reason for this discrepancy has not been established.

The work reported here has demonstrated that the techniques developed for the optimum application of automatic Karl Fischer reagent titration to the determination of $\mathrm{H}_{2} \mathrm{O}$ in solid materials, modified for the present case, can be used successfully under the constraints imposed by a glove box by an operator with no prior experience with the method.

The author is grateful to R. L. Moore, and G. J. Alkire of the Hanford Energy Development Laboratories who made it possible for the experimental work to be done there; to M. C. Burt who contributed in many ways to the success of the effort; to W. B. Larson who did the actual titration work in the glove box and the Moisture

${ }^{1}$ Certain commercial equipment and materials are identified in order to adequately specify the experimental procedure; such identification does not imply recommendation or endorsement by the National Bureau of Standards. 
Evolution Analyzer measurements; and to P. S. Schaus for consultation and for making the $\mathrm{PuO}_{2}$ available; and to Susan Johnson who typed the manuscript.

4. References

[1] Stakebake, J. L. The Storage Behavior of Plutonium Metal, Alloys, and Oxide; A review, J. Nucl. Mater. 38: 241-259; 1971.

[2] Stakebake, J. L. A Thermal Desorption Study of the Surface Interactions Between Water and Plutonium Dioxide, J. Phys. Chem. 77: 581-586; 1973.

[3] Stakebake, J. L. Water Vapor Adsorption on Plutonium Dioxide, J. Colloid Interface Sci., 42: 328-333; 1973.

[4] Jones, F. E. Determination of Water in Solids by Automatic Karl Fischer Titration, Anal. Chem. 53: 1955-1957; 1981.

[5] Jones, F. E. Telescopic Viewer in Syringe Calibration, Anal. Chem. 52:

[6] Jones, F. E.; Brickenkamp, C. S. Calculation of Solvent-Water Mixture Volumes, Anal. Chem. 53: 362-363; 1981. 
U.S. DEPT. OF COMM.

BIBLIOGRAPHIC DATA

SHEET (See in structions)
1. PUBLICATION OR REPORT NO.

NBSIR 82-2496
2. Performing Organ. Report No. 3. Publication Dare

April 1982

4. TITLE AND SUBTITLE

Determination of Water in Plutonium Dioxide

\section{5. $A \cup T H O R(S)$}

Frank E. Jones

6. PERFORMING ORGANIZATION (If joint or other than NBS. see instructions)

7. Contract Grant No.

NATIONAL BUFEAU OF STANDARDS

DEPARTMENT OF COMMERCE

WASHINGTON, D.C. 20234

8. Type of Report \& Period Covered

Final

9. SPONSORING ORGANIZATION NAME AND COMPLETE ADDRESS (Street, City, Stote, ZIP)

Office of Safeguards \& Security

U.S. Department of Energy

Washington, DC 20545

\section{SUPPLEMENTARY NOTES}

Document describes a computer program; SF-185, FIPS Software Summary, is attached.

11. ABSTRACT (A 200-word or less factual summary of most significant information. If document includes a significant tibliography or literature survey. mention it here)

Techniques developed to very effectively apply automatic Karl Fischer reagent titration to the determination of $\mathrm{H}_{2} \mathrm{O}$ in solids were used to determine the moisture content of samples of plutonium dioxide powder under the constraints imposed by the necessity of working in a glove box. The moisture contents of three samples were found to be $0.2934 \%, 0.7298 \%$, and $0.4640 \%$. The estimate of the relative standard deviation of the mean for three determinations on the $0.2934 \% \mathrm{H}_{2} \mathrm{O}$ sample was 0.0091 . The method apparently has potential as the basic reference method for determination of $\mathrm{H}_{2} \mathrm{O}$ in plutonium dioxide, as a means of standardizing other methods, and as a diagnostic tool.

12. KEY WORDS (Six to twelve entries; alphabetical order: copitalize only proper nomes; and separate key words by semicolons) Automatic titration, Karl Fischer reagent titration; moisture; nuclear safeguards, plutonium dioxide; water determination.

13. AVAILABILITY

Unlimited

For Official Distribution. Do Not Release to NTIS

Order From Superintendent of Documents, U.S. Government Printing Office, Washington, D.C. 20402.

X Order From National Technical Information Service (NTIS), Springfield, VA. 22I6I
14. NO.OF

PRINTED PAGES

5

15. Price

$\$ 6.00$ 

